\title{
EVALUASI PENILAIAN PEMBELAJARAN \\ PAI PADA KURIKULUM 2013 (K 13) \\ DALAM TATARAN PRAKTEK
}

\author{
Alwi mudhofar
}

\begin{abstract}
:
K13 curriculum which has been running since 2014 is able to change the mindsead of teachers to bring students to humans who are expected to have the character and competence. Learning evaluation is a series of activities to obtain, analyze, and interpret data about the learning process and learning outcomes of students carried out systematically and continuously. the problems that can be formulated include: 1). What is the input in the assessment of Islamic Religious Education learning in the 2013 Curriculum (K 13) ?, 2). What is the process of implementing the assessment of Islamic Religious Education learning in the 2013 Curriculum (K 13). Through field observations from several schools, it can be concluded; First, input evaluation, especially the qualifications of teaching staff in carrying out assessments including assessment design, indicators of competency achievement, assessment techniques and instruments, and how assessment processing has been met very well in accordance with established assessment standards. Second, the evaluation process (process), the assessment of the assessment system (affective, cognitive and psychomotor) and the implementation of the assessment process, shows the results that the process of carrying out the assessment of attitudes, knowledge and skills has been going well and conducive, only in the process of evaluating aspects of the teacher's attitude not going well.
\end{abstract}

Key word: Education assessment model K13

\section{A. LATAR BELAKANG}

Dalam sistem pendidikan di Indonesia, perubahan kurikulum sudah terjadi beberapa kali mulai dari kurikulum 1947 sampai dengan kurikulum terbaru yaitu kurikulum 2013. Perubahan kurikulum ini diharapkan dapat mengatasi permasalahan yang ada pada kurikulum sebelumnya yaitu KTSP (Kurikulum Tingkat Satuan Pendidikan). KTSP merupakan kurikulum yang dijalankan pemerintah pada tahun2006, kurikulum ini merupakan hasil penyempurnaan dari kurikulum sebelumnya..

Pengembangan kurikulum 2013 ini dilakukan karena adanya tantangan internal dan tantangan eksternal. Tantangan internal terkait tuntutan pendidikan yang mengacu pada 8 Standar Nasional Pendidikan dan faktor 
perkembangan penduduk Indonesia. Tantangan eksternal berkaitan dengan tantangan masa depan, kompetensi yang diperlukan di masa depan, persepsi masyarakat, perkembangan pengetahuan dan pedagogik, serta berbagai fenomena negatif yang mengemuka. Dengan kurikulum tujuan pendidikan nasional akan jelas arah yang akan ditempuh. Unsur-unsur yang terdapat dalam pokok kurikulum adalah tujuan, isi, materi, proses penyampaian materi, serta evaluasi. ${ }^{1}$

Evaluasi pembelajaran merupakan serangkaian kegiatan untuk memperoleh, menganalisis, dan menafsirkan data tentang proses dan hasil belajar peserta didik dilakukan secara sistematis dan berkesinambungan. ${ }^{2}$ Evaluasi inilah yang menjadi tolak ukur dari kemampuan pendidik dalam melaksanakan kegiatan belajar mengajar. Selain sebagai evaluasi pembelajaran yang dilakukan pendidik, evaluasi pembelajaran juga dapat menjadi ukuran dalam menganalisis pelaksanaan suatu kurikulum di sekolah/madrasah.

Pada tahun ajaran baru yaitu 2013/2014 Kurikulum 2013 mulai diberlakukan atau disingkat dengan $\mathrm{K} 13$, dalam kurikulum ini terdapat perubahan dan penyempurnaan dari kurikulum sebelumnya. Perubahan yang terdapat pada Kurikulum 2013 antara lain tentang proses pembelajaran melalui pendekatan saintifik dan penilaian autentik.

Faktanyapenilaian hasil belajar di madrasah/sekolah masih memfokuskan pada aspek kognitif. Penilaian hasil belajar sebaiknya secara komprehensif menekankan aspek afektif, kognitif, dan psikomotorik secara proposional dengan tetap mengacu pada kompetensi yang dituntut. Selain itu, penilaian tidak hanya mengetahui hasil belajar saja, tetapi bagaimana proses dalam mencapai hasil belajar.

Penilaian pendidikan pada Kurikulum 2013 sebagai proses pengumpulan dan pengolahan informasi untuk mengukur pencapaian hasil belajar peserta didik mencakup antara lain: penilaian otentik, penilaian diri,

\footnotetext{
${ }^{1}$ Nana Syaodin Sukmadinati, Pengembangan Kurikulum Teori dan Praktik (Bandung: PT Remaja Rosdakarya, 2012), hlm. 102.

${ }^{2}$ Sukiman, Pengembangan Sistem Evaluasi (Yogyakarta : Insan Madani, 2012), hlm. 11.
} 
penilaian berbasis portofolio, ulangan, ulangan harian, ulangan tengah semester, ulangan akhir semester, ujian tingkat kompetensi, ujian mutu tingkat kompetensi, ujian nasional, dan ujian sekolah/madrasah. ${ }^{3}$

Model yang dipakai dalam penelitian ini adalah evaluasi model CountenanceStake yang mempunyai tiga tahap, yaitu input, proses, dan output. Menurut S. Arikunto evaluasi program juga berarti upaya untuk mengetahui tingkat keterlaksanaan suatu kebijakan secara cermat dengan cara mengetahui efektivitas pelaksanaann masing-masing komponennya, baik terhadap program yang sedang berjalan maupun program yang telah berlaludengan mengambil keputusan. ${ }^{4}$

Berdasarkan konteks penelitian di atas, maka permasalahan yang dapat dirumuskan meliputi ;1). Bagaimana input dalam penilaian pembelajaran Pendidikan Agama Islam pada Kurikulum 2013 (K 13)?, 2).Bagaimana proses pelaksanaan penilaian pembelajaran Pendidikan Agama Islam pada Kurikulum 2013 (K 13)?

\section{B. KERANGKA BERFIKIR}

\section{Evaluasi model countenance stake}

Evaluasi merupakan suatu proses sistematis pengumpulan dan analisis informasi mutu. Evaluasi bukan sekedar menilai suatu aktifitas secara spontan dan insidental, melainkan merupakan kegiatan untuk menilai sesuatu secara terencana, sistematik dan terarah berdasarkan atas tujuan yang jelas. Kegiatan evaluasi memerlukan penggunaan informasi yang diperoleh melalui pengukuran maupun dengan cara lain untuk menentukan pendapat dan membuat keputusan pendidikan.

Evaluasi program merupakan proses untuk mendeskripsikan dan menilai suatu program dengan menggunakan kriteriatertentu dengantujuan untuk membantu merumuskan keputusan atau kebijakan yang lebih baik. Pertimbangannya adalah untuk memudahkan evaluator dalam

\footnotetext{
${ }^{3}$ Peraturan Menteri Pendidikan dan Kebudayaan Republik Indonesia Nomor 66 Tahun 2013 Tentang Standar Penilaian, hlm. 2.

${ }^{4}$ S. Eko Putro Widoyoko, Evaluasi Program Pembelajaran : Panduan Praktis Bagi Pendidik dan Calon Pendidik, (Yogyakarta : Pustaka Pelajar, 2009), hlm. 10.
} 
mendeskripsikan dan menilai komponen-komponen yang dinilai, apakah sesuai dengan ketentuan atau tidak.

Menurut S. Arikunto evaluasi program juga berarti upaya untuk mengetahui tingkat keterlaksanaan suatu kebijakan secara cermat dengan cara mengetahui efektivitas pelaksanaann masing-masing komponennya, baik terhadap program yang sedang berjalan maupun program yang telah berlaludengan mengambil keputusan. ${ }^{5}$

Ada empat kemungkinan kebijakan yang dapat dilakukan berdasarkan hasil pelaksanaan sebuah program, yaitu: a, Menghentikan program, karena dipandang bahwa program tersebut tidak ada manfaatnya atau tidak dapat terlaksana sebagaimana diharapkan. b. Merevisi program, karena ada bagian-bagian yang kurang sesuai dengan harapan (terdapat kesalahan tetapi hanya sedikit).c. Melanjutkan program, karena pelaksanaan program sudah berjalan sesuai dengan harapan dan memberikan hasil yang bermanfaat. D. Menyebarluaskan program, karena program berhasil dengan baik maka sangat baik jika dilaksanakan lagi di tempat dan waktu yang lain. ${ }^{6}$

Penelitian ini termasuk merevisi sekaligus melanjutkan program penilaian pada Kurikulum 2013. Evaluasi disni dipandang sebagai tindakan untuk menetapkan keberhasilan suatu program pendidikan, termasuk keberhasilan siswa dalam program pendidikan yang diikuti. Dengan demikian, evaluasi lebih menitikberatkan pada keberhasilan program atau kelompok guru termasuk dalam pelaksanaan penilaian PAI sesuai standar penilaian pendidikan.

Menurut Farida Yusuf Tayibnapis "Model Countenance Stake menekankan adanya pelaksanaan dua hal pokok, yaitu deskripsi (description) dan pertimbangan (judgments), serta membedakan adanya tiga tahap dalam evaluasi program, yaitu: 1) anteseden

\footnotetext{
${ }^{5}$ S. Eko Putro Widoyoko, Evaluasi Program Pembelajaran : Panduan Praktis Bagi Pendidik dan Calon Pendidik, (Yogyakarta : Pustaka Pelajar, 2009), hlm. 10.

6 Suharsimi Arikunto dan Cepi Syafruddin Abdul Jabar, Evaluasi Program Pendidikan, (Jakarta: Bumi Aksara, 2004), hlm. 8.
} 
(antecedents/context), 2) transaksi (transaction/process), dan 3) keluaran (output-outcomes). ${ }^{7}$ Description terdiri atas dua aspek, yaitu intents (goals) dan observation (effects) atau yang sebenarnya terjadi. Sedangkan judgement terdiri atas dua aspek, yaitu standard dan judgement. Dengan demikian selain mengungkapkan deskripsi dari evaluan juga mengutamakan adanya pertimbangan terhadap hasil evaluasi.

Pada setiap evaluasi program Stake terdapat tiga fokus diantaranya $:^{8}$

a. Antecedents(input) yaitu sebuah kondisi yang ada sebelum instruksi (program) yang mungkin berhubungan dengan hasil. Jadi antecedents adalah kondisi awal sebelum program diimplementasikan, contohnya: latar belakang guru dalam perencanaan penilaian, kurikulum yang sesuai, ketersediaan sumber daya manusia. Semua ini adalah contoh dari antecedent evaluator akan menggambarkan di penelitian evaluasi.

b. Transaction(proses) yaitu pertemuan dinamis yang merupakan proses instruksi (kegiatan, proses, dll). Jadi transaction adalah proses pelaksanaan program, contohnya: interaksi guru dan siswa, siswa dengan siswa, penulis dengan pembaca, orang tua dengan konselor, dan komponen partisipasi lainnya.

c. Outcomes(hasil) yaitu dampak dari pengalaman pembelajaran (pengamatan dan hasil tenaga kerja). Jadi outcomes adalah dampak implementasi pada akhir program, contohnya: performance guru, peningkatan kinerja sebelum program dilaksanakan, kemampuan, prestasi siswa, sikap yang dihasilkan dari pengalaman dalam kegiatan penilaian. Hasil sebagai informasi yang mencakup pengukuran pada guru, konselor, evaluator, dan lain-lain.

Dalam model ini adalah evaluator yang membuat penilaian tentang program yang dievaluasi. Evaluasi dilakukan dengan membandingkan antara satu program dengan program lain yang dianggap standar. Stake mengatakan description berbeda dengan judgement atau menilai. Dalam

\footnotetext{
${ }^{7}$ Farida Yusuf Tayibnapis, Evalausi Program (Jakarta : PT Rineka Cipta, 2000), hlm. 22.

${ }^{8}$ Robert. E. Stake, The Countenance Educational Evaluation, Center for Instructional Research and Curriculum Evaluation University of Illinois
} 
ketiga dimensi di atas antecedents (input), transaction (proses), dan outcomes (hasil) data tidak hanya dibandingkan untuk menentukan kesenjangan antara yang diperoleh dengan yang diharapkan, tetapi juga dibandingkan dengan standar yang mutlak, untuk menilai manfaat program. Stake mengatakan bahwa suatu hasil penelitian tidak dapat diandalkan jika tidak dilakukan evaluasi. ${ }^{9}$

Kategori pertama dari matrik deskripsi adalah sesuatu yang direncanakan dalam pengembangkan kurikulum atau program. Misalnya, seorang guru sebagai pelaksana dan pelapor penilaian pada satuan pendidikan, merencanakan persyaratan dalam kegiatan penilaian. Apakah persyaratan yang berhubungan dengan pendidik seperti minat, kemampuan, dan pengalaman dalam penilaian, yang biasa diistilahkan dengan entry behaviors, ataupun persyaratan yang berhubungan dengan lingkungan di kelas, yang kesemuanya dapat dicantumkan dalam antecedent yang direncanakan. Lebih lanjut, guru tersebut merencanakan apa yang diperkirakan akan terjadi pada waktu interaksi di kelas, dan kemampuan apa yang diharapkan dimiliki peserta didik setelah proses interaksi berlangsung. ${ }^{10}$

Kategori kedua, dinamakan observasi, yakni berhubungan dengan apa yang sesungguhnya terjadi sebagai implementasi dari rencana di kategori pertama.Pada kategori ini evaluator harus melakukan observasi (pengumpulan data) mengenai input, proses dan hasil. Oleh karena itu evaluator harus memahami apa yang direncanakan sebelumnya, menentukan data yang diperlukan dan mengembangkan prosedur atau instrumen untuk mengumpulkan data yang diperlukan.

Sedangkan padamatrik kedua pertimbangan terdiri atas kategori standar dan kategori pertimbangan yang tetap fokus pada input, proses dan hasil yang diperoleh. Standar adalah kriteria yang harus dipenuhi oleh suatu program yang dijadikan evaluan. Dalam hal ini adalah kriteriayang harus

\footnotetext{
${ }^{9}$ Farida Yusuf Tayibnapis, Evalausi Program, hlm. 22.

${ }^{10}$ S. Hamid Hasan, Evaluasi Kurikulum, (Bandung: Remaja Rosdakarya, 2008), hlm. 208.
} 
dipenuhi dalam penilaian, evaluator dapat mengambil standar penilaian pada kurikulum 2013 yang telah ditentukan oleh sekolah/madrasah maupun pemerintah terhadap standar nasional pendidikan (SNP).

Kategori kedua adalah kategori pertimbangan. Kategori ini menghendaki evaluator melakukan pertimbangan dari apa yang telah dilakukan dari kategori pertama dan kedua matrik deskripsi dan kategori pertama dari matrik pertimbangan. Evaluator harus mengumpulkan data mengenai pertimbangan tersebut dari sekelompok orang yang dianggap memiliki kualifikasi untuk memberikan pertimbangan tersebut.

\section{Langkah-langkah evaluasi model countenance stake}

Sebelum langkah-langkah pelaksanaan evaluasi countenance Stake terlebih dahulu di jelaskan keseluruhan konsep countenance Stake yang digambarkan sebagai berikut:

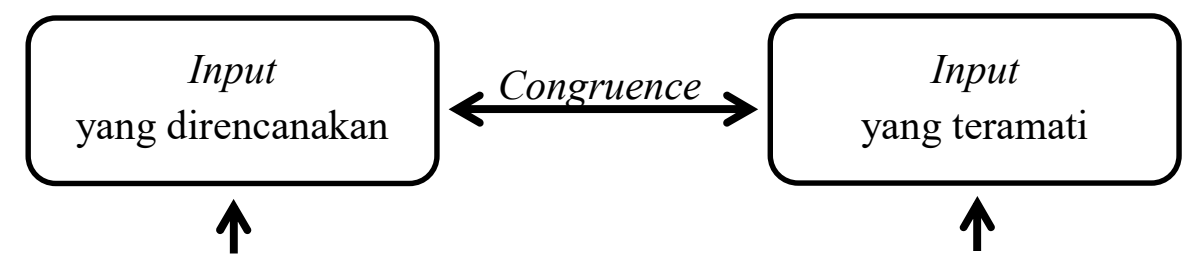

Contigency Logis Contigency Empirik

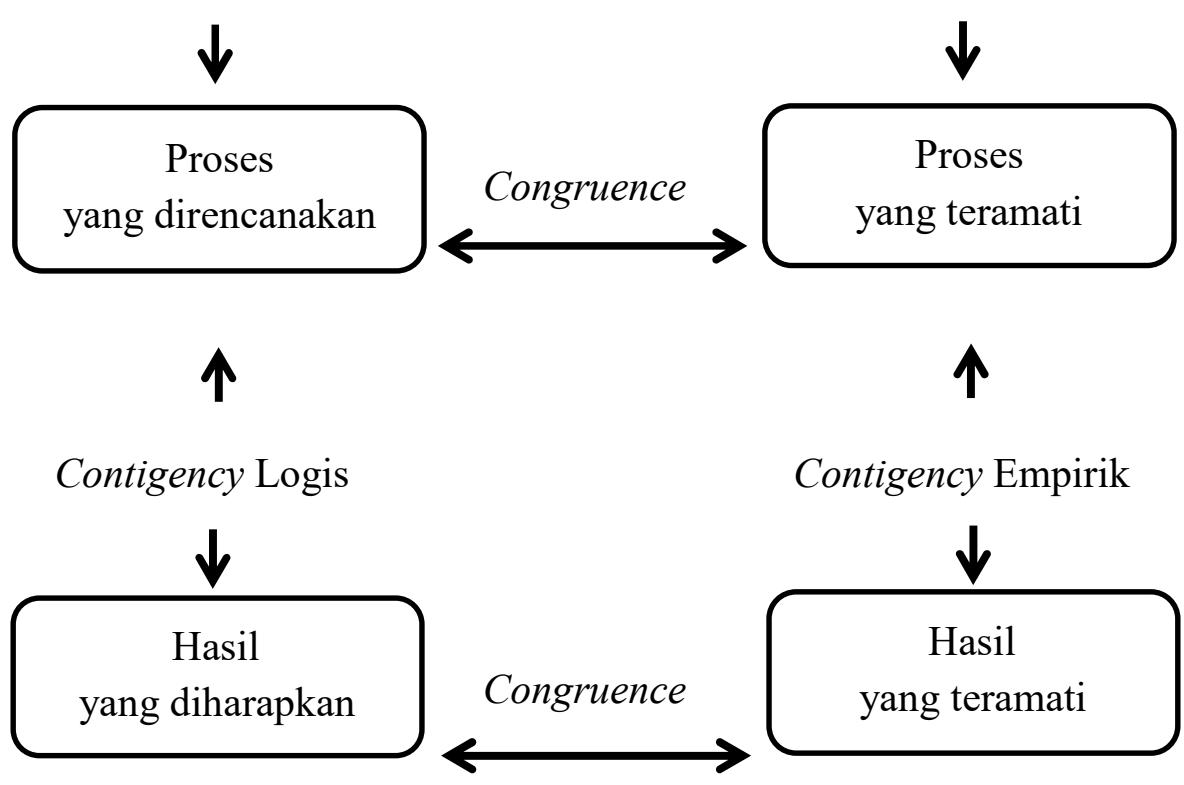

Gambar 2. Model Pengolahan Data Deskripsi 
Contigency terdiri atascontingencylogisdancontingencyempirik. Contingencylogisadalahhasilpertimbangan

evaluator terhadapketerkaitanataukeselarasanlogisantarakotakInputdenganprosesdan hasil.Iniadalahpertimbanganpertama yang harusdilakukan evaluator.

Sedangkan contingency empirikadalah hasil pertimbangan evaluator terhadap keterkaitan atau keselarasan empirik antara kotak inputdengan proses dan hasil berdasarkan data lapangan. Selain itu, evaluator juga harus memberikan pertimbangan mengenai congruence atau perbedaan yang terjadi antara rencana dengan kenyataan di lapangan.

Adapun langkah-langkah yang harus ditempuh dalam melaksanakan evaluasi countenance Stake tercakup dalam empat langkah berdasarkan empat matriks, yaitu :

a. Sehubungan dengan kategori intent, evaluator dapat melakukan observasi dan studi dokumen atau wawancara kepada pengembang program, baik berhubungan dengan input (persyaratan awal), proses serta hasil. Dalam hal penilaian dapat dilakukan dengan mempersiapkan rencana penilaian yang dituangkan dalam silabus, RPP dan kisi-kisi penilaian serta instrumen yang dibutuhkan untuk tes dan non-tes.

b. Sehubungan dengan kategori observasi, evaluator harus mengadakan analisis kongruen, yaitu menganalisa implementasi dari rencana pada intent. Apakah sesuai atau terjadi penyimpangan, jika terjadi penyimpangan faktor-faktor apa yang menyebabkannya.

c. Tugas evaluator berikutnya adalah memberikan pertimbangan mengenai program yang sedang dikaji, oleh karenanya perlu standar yang dapat diperoleh dari sekolah/madrasah.

d. Dan yang terakhir adalah memberi pertimbangan terhadap hasil dari analisis ketiga kategori sebelumnya. Pertimbangan dapat diperoleh dengan mengumpulkan data dari sekelompok orang yang memiliki kualifikasi untuk memberikan pertimbangan. Dalam pembelajaran pertimbangan dapat berdasarkan faktor karakteristik 
siswa,saranaprasarana sekolah/madrasah dan standar penilaian Kurikulum 2013 yang dituangkan dalam Standar Pendidikan Nasional. ${ }^{11}$

\section{PENILAIAN AUTENTIK PADA KURIKULUM 2013}

Berdasarkan Kurikulum 2013, penilaian hasil belajar adalah proses pengumpulan informasi/bukti tentang capaian pembelajaran peserta didik dalam kompetensi sikap spiritual dan sikap sosial, kompetensi pengetahuan, dan kompetensi keterampilan yang dilakukan secara terencana dan sistematis, selama dan setelah proses pembelajaran suatu kompetensi muatan pembelajaran untuk kurun waktu satu semester dan satu tahun pelajaran. ${ }^{12}$ Penilaian yang digunakan adalah penilaian autentik, yaitu bentuk penilaian yang menghendaki peserta didik menampilkan sikap, pengetahuan dan keterampilan yang diperoleh dari pembelajaran dalam melakukan tugas situasi yang sesungguhnya.

Penilaian proses pembelajaran menggunakan pendekatan penilaian otentik (authentic assesment) yang menilai kesiapan siswa, proses, dan hasil belajar secara utuh. Keterpaduan penilaian ketiga komponen tersebut akan menggambarkan kapasitas, gaya, dan perolehan belajar siswa atau bahkan mampu menghasilkan dampak instruksional (instructional effect) dan dampak pengiring (nurturant effect) dari pembelajaran. ${ }^{13}$

Hasil penilaian otentik dapat digunakan oleh guru untuk merencanakan program perbaikan (remedial), pengayaan (enrichment), atau pelayanan konseling. Selain itu, sebagai bahan untuk memperbaiki proses pembelajaran sesuai dengan Standar Penilaian Pendidikan.Evaluasi proses pembelajaran dilakukan saat proses pembelajaran dengan menggunakan alat: angket, observasi, catatan anekdot, dan refleksi. ${ }^{14}$

\footnotetext{
${ }^{11}$ S. Hamid Hasan, Evaluasi Kurikulum, hlm. 212.

${ }^{12}$ Direktorat Pembinaan Sekolah Menengah Atas-Direktorat Jenderal Pendidikan Menengah, Kementerian Pendidikan dan Kebudayaan, Panduan e-Rapor SMA, 2014, hlm. 1.

${ }^{13}$ Peraturan Menteri Pendidikan dan Kebudayaan Republik Indonesia Nomor 65 Tahun 2013 Tentang Standar Proses Pendidikan Dasar dan Menengah, hlm. 11.

${ }^{14}$ Peraturan Menteri Pendidikan dan Kebudayaan Republik Indonesia Nomor 65 Tahun 2013 Tentang Standar Proses Pendidikan Dasar dan Menengah, hlm. 11.
} 
Disamping itu guru harus memperhatikan beberapa hal-hal dalam merancang penilaian, diantaranya adalah :

a. Penilaian diarahkan untuk mengukur pencapaian kompetensi yaitu KD-KD pada KI-3 dan KI-4.

b. Penilaian menggunakan acuan kriteria yaitu berdasarkan apa yang bisa dilakukan peserta didik setelah mengikuti proses pembelajaran, dan bukan untuk menentukan posisi seseorang terhadap kelompoknya.

c. Sistem yang direncanakan adalah sistem penilaian yang berkelanjutan. Berkelanjutan dalam arti semua indikator ditagih, kemudian hasilnya dianalisis untuk menentukan KD yang telah dimiliki dan yang belum, serta untuk mengetahui kesulitan peserta didik.

d. Hasil penilaian dianalisis untuk menentukan tindak lanjut. Tindak lanjut berupa perbaikan proses pembelajaran berikutnya, program remedi bagi peserta didik yang pencapaian kompetensinya di bawah ketuntasan, dan program pengayaan bagi peserta didik yang telah memenuhi ketuntasan.

e. Sistem penilaian harus disesuaikan dengan pengalaman belajar yang ditempuh dalam proses pembelajaran. Misalnya, jika pembelajaran menggunakan pendekatan tugas observasi lapangan maka evaluasi harus diberikan baik pada proses hasil melakukan observasi lapangan. ${ }^{15}$

\section{INSTRUMEN PENILAIAN KURIKULUM 2013}

Adapun berdasarkan Peraturan Menteri Pendidikan dan Kebudayaan Republik Indonesia Nomor 66 Tahun 2013 tentang Standar Penilaian, bahwa teknik dan instrumen yang digunakan untuk penilaian kompetensi sikap, pengetahuan, dan keterampilan adalah sebagai berikut. ${ }^{16}$

a. Penilaian Kompetensi Sikap

Pendidik melakukan penilaian kompetensi sikap melalui observasi, penilaian diri, penilaian "teman sejawat" (peer evaluation) oleh peserta didik dan jurnal. Instrumen yang digunakan untuk observasi, penilaian

\footnotetext{
${ }^{15}$ Peraturan Menteri Pendidikan Dan KebudayaanRepublik Indonesia Nomor 81a Tahun 2013 TentangImplementasi Kurikulum, hlm. 41-42.

${ }^{16}$ Peraturan Menteri Pendidikan dan Kebudayaan Republik Indonesia Nomor 66 Tahun 2013 Tentang Standar Penilaian, hlm. 4-5.
} 
diri, dan penilaian antar peserta didik adalah daftar cek atau skala penilaian (rating scale) yang disertai rubrik, sedangkan pada jurnal berupa catatan pendidik.1). Observasi merupakan teknik penilaian yang dilakukan secara berkesinambungan dengan menggunakan indera, baik secara langsung maupun tidak langsung dengan menggunakan pedoman observasi yang berisi sejumlah indikator perilaku yang diamati.2).

Penilaian diri merupakan teknik penilaian dengan cara meminta peserta didik untuk mengemukakan kelebihan dan kekurangan dirinya dalam konteks pencapaian kompetensi. Instrumen yang digunakan berupa lembar penilaian diri.). Penilaian antarpeserta didik merupakan teknik penilaian dengan cara meminta peserta didik untuk saling menilai terkait dengan pencapaian kompetensi. Instrumen yang digunakan berupa lembar penilaian antarpeserta didik. 3). Jurnal merupakan catatan pendidik di dalam dan di luar kelas yang berisi informasi hasil pengamatan tentang kekuatan dan kelemahan peserta didik yang berkaitan dengan sikap dan perilaku.

b. Penilaian Kompetensi Pengetahuan

Pendidik menilai kompetensi pengetahuan melalui tes tulis, tes lisan, dan penugasan. Sebelum melaksanakan penilaian kompetensi pengetahuan, pendidik telah menyiapkan instrumen penilaian yang meliputi: (1) Instrumen tes tulis berupa soal pilihan ganda, isian, jawaban singkat, benar-salah, menjodohkan, dan uraian. Instrumen uraian dilengkapi pedoman penskoran; (2) Instrumen tes lisan berupa daftar pertanyaan; (3) Instrumen penugasan berupa pekerjaan rumah dan/atau projek yang dikerjakan secara individu atau kelompok sesuai dengan karakteristik tugasyang akan dikerjakan peserta didik.

c. Penilaian Kompetensi Keterampilan

Untuk mengetahui kompetensi keterampilan, seorang pendidik harus menilai kompetensi keterampilan melalui penilaian kinerja, yaitu penilaian yang menuntut peserta didik mendemonstrasikan suatu kompetensi tertentu dengan menggunakan tes praktik, projek, dan 
penilaian portofolio. Instrumen yang digunakan berupa daftar cek (checklist) atau skala penilaian (rating scale) yang dilengkapi rubrik.

Elemen Perubahan Penilaian Standar Nasional pada Kurikulum 2013 untuk Jenjang Sekolah Menegah Atas(SMA)/Madrasah Aliyah (MA) :

Elemen Perubahan Penilaian padaKurikulum 2013

\begin{tabular}{|c|c|}
\hline Elemen & Deskripsi \\
\hline $\begin{array}{l}\text { Standar } \\
\text { Penilaian }\end{array}$ & $\begin{array}{l}\text { - } \text { Penilaian berbasis kompetensi. } \\
\text { - Pergeseran dari penilaian melalui tes (mengukur kompetensi } \\
\text { pengetahuan berdasarkan hasil saja), menuju penilaian } \\
\text { otentik (mengukur semua kompetensi sikap, pengetahuan, } \\
\text { dan keterampilan berdasarkan proses dan hasil). } \\
\text { - Memperkuat PAP (Penilaian Acuan Patokan) yaitu } \\
\text { pencapaian hasil belajar didasarkan pada posisi skor yang } \\
\text { diperoleh terhadap skor ideal (maksimal). } \\
\text { - Penilaian tidak hanya pada level KD, tetapi juga pada KI } \\
\text { dan SKL. } \\
\text { Mendorong pemanfaatan portofolio yang dibuat siswa } \\
\text { sebagai instrumen utama penilaian. }\end{array}$ \\
\hline
\end{tabular}

(Sumber : Kemendikbud, 2013) ${ }^{17}$

Perbedaan Penilaian Tradisional dengan Penilaian Autentik

\begin{tabular}{|c|l|l|}
\hline No & \multicolumn{1}{|c|}{ Penilaian Tradisional (KTSP) } & \multicolumn{1}{|c|}{ Penilaian Autentik (K13) } \\
\hline 1 & $\begin{array}{l}\text { Penilaian menekankan pada peringkat } \\
\text { dan mengklasifikasi-kan siswa }\end{array}$ & $\begin{array}{l}\text { Penilaian menekankan pada } \\
\text { kompetensi yang diajarkan }\end{array}$ \\
\hline 2 & $\begin{array}{l}\text { Mengesampingkan siswa yang yang } \\
\text { tidak mampu (lemah) }\end{array}$ & $\begin{array}{l}\text { Membantu siswa yang yang lemah } \\
\text { untuk berkembang }\end{array}$ \\
\hline 3 & $\begin{array}{l}\text { Peringkat dan klasifikasi cenderung } \\
\text { mendorong kompetisi yang berlebihan }\end{array}$ & $\begin{array}{l}\text { Penilaian kompetensi cenderung } \\
\text { membangun semangat kerja sama }\end{array}$ \\
\hline
\end{tabular}

\footnotetext{
${ }^{17}$ Kemendikbud, 2012, Bahan Uji Publik Kurikulum 2013, (ONLINE), (http://icls.upi.edu/v5/forum/download/file.php?id=113\&sid=00972dea9f89ab52ca5c5a302916d3c 6), diakses pada tanggal 09 Februari 2015 .
} 


\begin{tabular}{|c|l|l|}
\hline 4 & $\begin{array}{l}\text { Penilaian hanya menitik-beratkan pada } \\
\text { aspek kognitif (pengetahuan) }\end{array}$ & $\begin{array}{l}\text { Penilaian menitikberatkan pada tiga } \\
\text { aspek, yaitu afektif, kognitif, dan } \\
\text { psikomotorik secara proporsional. }\end{array}$ \\
\hline 5 & $\begin{array}{l}\text { Pengumpulan informasi nilai hanya } \\
\text { dengan TES }\end{array}$ & $\begin{array}{l}\text { Pengumpulan informasi nilai } \\
\text { dengan TES dan NON-TES }\end{array}$ \\
\hline
\end{tabular}

(Sumber: Munib Chatib, 2012) ${ }^{18}$

\section{E. EVALUASI PENILAIAN PAI PADA KURIKULUM 2013}

Evaluasi penilaian dalam pembahasan ini menggunakan Model evaluasi Stake yaitu menekankan adanya dua dasar kegiatan dalam evaluasi, description dan judgement dan membedakan adanya tiga tahap dalam program pendidikan, yaitu input (antecedent/context), proses (transaction/process), dan hasil (output-outcomes). Stake mengemukakan bahwa apabila menilai suatu program pendidikan, kita melakukan perbandingan yang relatif antara satu program dengan yang lain, atau perbandingan yang absolut yaitu membandingkan suatu program dengan standar tertentu. ${ }^{19}$

Tahapan dalam evaluasi pendidikan model Stake. Pertama input, menurut Arikunto, "penilaian terhadap input guru dilakukan untuk mengetahui kinerja guru ketika kegiatan penilaian di kelas sudah baik, artinya menggunakan teknik penilaian yang tepat”. Peraturan Menteri Pendidikan Nasional Nomor 20 Tahun 2007 tentang standar penilaian nasional memberikan patokan dalam penilaian pembelajaran di sekolah, pendidik (guru) adalah tenaga profesional sebagaimana diamanatkan dalam pasal 39 ayat 2, UU RI No. 20 Tahun 2003. Robert. Stake mengungkapkan bahwa Antecedents/input adalah sebuah kondisi yang ada sebelum instruksi (program) yang mungkin berhubungan dengan hasil. Jadi antecedents adalah kondisi awal sebelum program diimplementasikan, contohnya: latar belakang guru dalam perencanaan penilaian, kurikulum yang sesuai,

\footnotetext{
${ }^{18}$ Munif Chotib, Sekolahnya Manusia, (Bandung : MMU, 2012), Cet XII, hlm. 155.

${ }^{19}$ S. Eko Putro Widoyoko, Evaluasi Program Pembelajaran, hlm. 187.
} 
ketersediaan sumber daya manusia. Semua ini adalah contoh dari antecedents yang evaluator akan menggambarkan di penelitian evaluasi. ${ }^{20}$

Menurut Depdiknas menyatakan bahwa "untuk mengetahui kompetensi guru dalam menyusun penilaian belajar siswa, meliputi : (a) mampu memilih soal berdasarkan tingkat kesukaran, (b) mampu memilih soal berdasarkan tingkat pembeda, (c) mampu memperbaiki soal yang tidak valid (mampu memeriksa jawaban), (d) mampu mengklasifikasikan hasil penilaian, (e) mampu mengolah dan menganalisis hasil penilaian, (f) mampu memperoleh korelasi soal berdasarkan hasil penilaian, (g) mampu mengidentifikasi tingkat variasi hasil penilaian, (h) mampu menyimpulkan hasil penilaian, (i) mampu menyusun program tindak lanjut hasil penilaian, (j) mampu mengklasifikasikan kemampuan siswa, (k)mampu melaksanakan tindak lanjut, (1) mampu mengevaluasi hasil tindak lanjut, dan (m) mampu menganalisis hasil program tindak lanjut.

Sebelum pelaksanaan penilaian, guru yang berkualitas telah mempersiapkan dengan baik dan menentukan apa yang seharusnya dinilai, bagaimana penilaian itu harus dilakukan dan tindakan apa saja yang harus dilakukan setelah pelaksanaan penilaian. Selain itu seorang pendidik juga harus mampu membuat format/soal yang sesuai dengan materi yang diajarkan, karena tidak semua mata pelajaran bisa menggunakan teknik penilaian yang sama.

Kedua proses, yaitu pertemuan dinamis yang merupakan proses instruksi (kegiatan, proses, dll). Proses pelaksanaan program, contohnya : interaksi guru dan siswa, siswa dengan siswa, penulis dengan pembaca, orang tua dengan konselor, dan komponen partisipasi lainnya. Proses yang dinamis sedangkan inputdan hasil relatif statis. Hal ini sebagai batas selama proses dapat mengidentifikasi hasil dari input sebagai umpan balik untuk

\footnotetext{
20 Robert. E. Stake, The Countenance Educational Evaluation, Center for Instructional Research and Curriculum Evaluation University of Illinois
} 
kegiatan penilaian berikutnya, bukan untuk perbedaan, tetapi berfungsi sebagai pengingat dan pelengkap dalam pengumpulan data. ${ }^{21}$

\section{F. HASIL PENGAMATAN DALAM TATARAN PRATEK}

Penelitian ini evaluasi penilaian pembelajaran PAI pada Kurikulum 2013 dengan menggunakan model evaluasi Stake. Menurut Farida Yusuf Tayibnapis "Model Countenance Stake menekankan adanya pelaksanaan dua hal pokok, yaitu deskripsi (description) dan pertimbangan (judgments), serta membedakan adanya tiga tahap dalam evaluasi program, yaitu: 1) Input2) Proses dan 3) Hasil. ${ }^{22}$ Description terdiri atas dua aspek, yaitu intents (goals) dan observation (effects) atau yang sebenarnya terjadi. Sedangkan judgement terdiri atas dua aspek, yaitu standard dan judgement.

Menurut evaluasi model Stake, ketika evaluator tengah mempertimbangkan program pendidikan mau tidak mau harus melakukan dua perbandingan, yaitu $:^{23}$

a. Membandingkan kondisi hasil evaluasi program tertentu dengan yang terjadi di program lain, dengan sasaran yang sama.

b. Membandingkan kondisi hasil pelaksanaan program dengan standar yang diperuntukkan bagi program yang bersangkutan, didasarkan pada tujuan yang akan dicapai.

\section{Evaluasi input}

Robert. Stake mengungkapkan bahwa input merupakan sebuah kondisi yang ada sebelum program yang mungkin berhubungan dengan hasil. Jadi input adalah kondisi awal sebelum program diimplementasikan, contohnya: latar belakang guru dalam perencanaan penilaian, kurikulum yang sesuai, ketersediaan sumber daya manusia. ${ }^{24}$

Pada tahapan ini yang dievaluasi yaitu kesiapan guru dalam melakukan penilaian autentik dalam pembelajaran PAI. Kesiapan tersebut

\footnotetext{
${ }^{21}$ Robert. E. Stake, The Countenance Educational Evaluation, Center for Instructional Research and Curriculum Evaluation University of Illinois

${ }^{22}$ Farida Yusuf Tayibnapis, Evalausi Program (Jakarta : PT Rineka Cipta, 2000), hlm. 22.

${ }^{23}$ Arikunto dan Safrudin, Evaluasi Program Pendidikan, hlm. 44.

${ }^{24}$ Robert. E. Stake, The Countenance Educational Evaluation, Center for Instructional Research and Curriculum Evaluation University of Illinois.
} 
dicerminkan dengan guru membuat perencanaan penilaian autentik. Evaluasi fase input berorientasi pada suatu program yang dapat dicapai dan apa yang diinginkan, sub-sub komponen yang menjadi fokus dalam mengevaluasi program penilaian autentik adalah perencanaan penilaian sikap, perencanaan penilaian pengetahuan, dan perencanaan penilaian keterampilan.

Penilaian autentik perlu dilakukan secara terprogram dan sistematis. Oleh karena itu, perlu dipersiapkan dengan langkah-langkah yang jelas dan tepat. Langkah-langkah penilaian autentik dituangkan dalam perencanaan penilaian. Dalam perencanaan penilaian terdapat rancangan penilaian secara terinci, menentukan teknik dan instrumen penilaian, dan menentukan pengolahan nilai. Perencanaan penilaian terintegrasi dalam rencana pelaksanaan pembelajaran (RPP) dan silabus. Perencanaan merupakan acuan dalam melaksanaan penilaian autentik dalam pembelajaran. Perencanaan penilaian autentik terdiri dari perencanaan penilaian sikap, perencanaan penilaian pengetahuan dan perencanaan penilaian keterampilan.

Hal-hal yang perlu diperhatikan dalam merumuskan indikator: (a) setiap kompetensi dasar (KD) dikembangakan menjadi beberapa indikator, (b) keseluruhanan indikator memenuhi tuntutan kompetensi yang tertuang dalam kata kerja yang digunakan dalam KI-KD, (c) indikator dimulai dari tingkatan berpikir mudah ke sukar, sederhanan ke kompleks, dekat ke jauh, dan dari konkret ke abstrak, (d) indikator harus menggambarkan hierarki kompetensi, (e) rumusan indikator sekurang-kurangnya mencakup dua aspek, yaitu tingkat kompetensi dan materi pembelajaran, (f) indikator harus dapat mengakomodasi karakteristik mata pelajaran sehingga menggunakan kata kerja operasional yang sesuai, (g) rumusan indikator dapat dikembangkan menjadi beberapa indikator penilaian yang mencakup ranah kognitif, afektif, dan psikomotorik. ${ }^{25}$

\footnotetext{
${ }^{25}$ Kusnandar, Penilaian Autentik : Penilaian Hasil Belajar Peserta Didik Berdasarkan Kurikulum 2013 (Jakarta: Raja Grafindo Persada, 2013), hlm. 93.
} 
Perencanaan yang dibuat guru menunjukan bahwa rancangan penilaian autentik dibuat secara rinci di dalam rencana pelaksanaan pembelajaran. Guru sudah merencanakan jenis penilaian, teknik penilaian, bentuk penilaian, dengan cukup baik. Tetapi pada aspek pembuatan rubrik, kriteria, dan pedoman kurang sesuai dengan standar objektif penilaian. Di samping itu, guru juga sudah mempersiapkan instrumen penilaian sesuai dengan teknik penilaian sebelum melakukan penilaian autentik.

\section{Evaluasi proses}

Evaluasi proses dinilai berdasarkan Permendikbud Nomor 104 Tahun 2014 tentang standar penilaian autentik untuk Satuan Pendidikan Dasar dan Menengah. Standar proses yang dimaksud meliputi : (1) penginformasian sistem penilaian (afektif, kognitif dan psikomotorik); dan (2) pelaksanaan proses penilaian.

Proses pelaksanaan penilaian autentik dilakukan setelah prosesbelajar mengajar. Penilaian secara esensial bertujuan untuk mengukur keberhasilan pembelajaran yang dilakukan oleh guru dan sekaligus mengukur keberhasilan peserta didik dalam penguasaan kompetensi yang ditentukan. Tahap ini merupakan tahap implementasi atau tahap penerapan atas desain perencanaan yang telah dibuat guru. Hakikat dari tahap pelaksanaan adalah kegiatan operasional penilaian itu sendiri. Salah satu aspek yang mempengaruhi keberhasilan penilaian adalah kemampuan guru dalam mengelola penilaian dan membuat instrumen penilaian autentik. Jika instrumen penilaian yang disusun oleh guru tidak sesuai dengan karakteristik dan kompleksitas materi yang ada di standar isi dan Standar Kompetensi Lulusan (SKL), maka instrumen tersebut tidak akan memberikan informasi yang akurat tentang tingkat pencapaian kompetensi peserta didik. Instrumen yang digunakan guru harus merangsang kemampuan berpikir tingkat tinggi, logika dan analisis dari peserta didik. 
Dengan demikian, penilaian autentik yang dilakukan guru mencerminkan kompetensi peserta didik secara nyata. ${ }^{26}$

Proses pelaksanaan penilaian autentik dalam proses pembelajaran diawali dengan penelusuran dan diakhiri dengan tes dan non-tes. Penelusuran dilakukan dengan menggunakan teknik bertanya untuk mengekplorasi pengalaman belajar sesuai dengan kondisi dan tingkat kemampuan peserta didik. Dalam proses pembelajaran guru melakukan penilaian terhadap kompetensi sikap yaitu dengan melakukan pengamatan terhadap peserta didik. Penilaian kompetensi sikap adalah penilaian yang dilakukan guru untuk mengukur tingkat pencapaian kompetensi sikap dari peserta didik yang meliputi memperhatikan, mengelola, menghargai, dan berkarakter. $^{27}$

Dalam kurikulum 2013 kompetensi sikap dibagi menjadi dua, yakni sikap spiritual (KI-1) dan sikap inti (KI-2) untuk sikap sosial. Dalam melakukan penilaian sikap guru menggunakan instrumen lembar pengamatan yang berisi daftar peserta didik dan sikap yang akan dinilai serta rubrik penilaian dan pengolahan nilainya. Penilaian selanjutnya pada aspek pengetahuan. Penilaian kompetensi pengetahuan adalah penilaian yang dilakukan guru untuk mengukur tingkat pencapaian ataua penguasaan peserta didik dalam aspek pengetahuan yang meliputi ingatan atau hafalan, pemahaman, penerapan atau aplikasi, analisis, sintesis, dan evaluasi. ${ }^{28}$

Dalam kurikulum 2013 kompetensi pengetahuan dibagi menjadi kompetensi inti 3 (KI-3). Kompetensi pengetahuan merefleksikan konsepkonsep keilmuan yang harus dikuasai oleh peserta didik melalui proses belajar mengajar. Penilaian autentik dalam aspek pengetahuan dapat dilakukan selama prosesdan sesudah proses pembelajaran. Teknik yang digunakan adalah tes tertulis dan tes lisan. Instrumen penilaian pengetahuan dengan teknik tes tertulis terdiri dari: (a) soal pilihan ganda, (b) isian, dan (c) uraian. Sedangkan teknik tes lisan berupa hafalan,

\footnotetext{
${ }^{26}$ Kusnandar, Penilaian Autentik, hlm. 11.

${ }^{27}$ Kusnandar, Penilaian Autentik, hlm. 100.

${ }^{28}$ Kusnandar, Penilaian Autentik, hlm. 159.
} 
instrumennya berbentuk daftar pertanyaan yang akan ditanyakan secara langsung.

Penilaian autentik pada aspek keterampilan dilakukan guru untuk mengukur tingkat pencapaian kompetensi keterampilan dari peserta didik. Dalam kurikulum 2013 kompetensi keterampilan menjadi kompetensi inti 4 (KI-4). Kompetensi inti 4 tidak dapat dipisahkan dengan kompetensi 3 (KI-3) yaitu pengetahuan. Penilaian keterampilan dapat menggunankan bentuk penilaian praktek, unjuk kerja, proyek, portofolio, dan penilaian produk.

\section{G. KESIMPULAN}

Berdasarkan hasil penelitian dan pembahasannya, dapat disimpulkan sebagai berikut :

Pertama, evaluasiinput, utamanya kualifikasi tenaga pendidik dalam melaksanakan penilaian mencakup rancangan penilaian, indikator pencapaian kompetensi, teknik dan instrumen penilaian, dan cara pengolahan penilaian sudah terpenuhi dengan sangatbaik sesuai dengan standar penilaian yang ditetapkan. Beberapa hal yang menjadi catatan diantaranya masih kurangnya buku panduan tentang penilaian autentik, penilaian yang rumit mengakibatkan kurangnya pemahaman dalam membuat instrumen penilaian yang baik dan benar sehingga membingungkan guru dalam merencanakan penilaian hasil belajar. Oleh karena itu dibutuhkan pihak pemerintah mensosialisasikan penilaian autentik kepada guru madrasah dengan pelatihan, pembinaan dan monitoring secara komprehensif dan berkesinambungan dan buku panduan siap didistribusikan di sekolah/madrasah untuk KBM agar tepat sasaran dalam melakukan penilaian hasil belajar pada Kurikulum 2013.

Kedua,evaluasi proses (process), pada penginformasian sistem penilaian (afektif, kognitif dan psikomotorik) dan pelaksanaan proses penilaian, menunjukkan hasil bahwa proses pelaksanaan penilaian sikap, pengetahuan dan keterampilan telah berjalan dengan baik dan kondusif, hanya pada proses pelaksanaan penilaian aspek sikap guru belum berjalan 
dengan baik. Hal ini belum sesuai dengan yang diharapkan pada kurikulum 2013 dan masih menggunakan sistem KTSP. Beberapa hal yang menjadi catatan diantaranya adalah terkait banyaknya siswa yang dinilai setiap aspek penilaian dan kurangnya kesiapan dalam melaksanakan penilaian. Oleh karena itu dibutuhkan perangkat penilaian yang lengkap sebelum KBM dan tiap pertemuan membatasi siswa yang akan dinilai.

\section{DAFTAR PUSTAKA}

Arikunto dan Safrudin. 2010. Evaluasi Program Pendidikan : Pedoman Teoritis Praktis bagi Mahasiswa dan Praktisi Pendidikan (Edisi Kedua). Jakarta : Bumi Aksara

BSNP, Standar Penilaian Badan Standar Nasional Pendidikan, (ONLINE, 2006), (http://www.scribd.com/doc/57794738/PENILAIAN-STANDAR-BSNP)

Chotib, Munif. 2012. Sekolahnya Manusia. Bandung : MMU

Kusnandar. 2013. Penilaian Autentik : Penilaian Hasil Belajar Peserta Didik Berdasarkan Kurikulum 2013. Jakarta: Raja Grafindo Persada

Peraturan Menteri Pendidikan dan Kebudayaan Republik Indonesia Nomor 65 tahun 2013 Tentang Standar Proses Pendidikan Dasar dan Menengah

Peraturan Menteri Pendidikan dan Kebudayaan Republik Indonesia Nomor 66 Tahun 2013 Tentang Standar Penilaian

Peraturan Menteri Pendidikan dan Kebudayaan Republik Indonesia Nomor 104 Tahun 2014 tentang Penilaian Hasil Belajar oleh Pendidik pada Pendidikan Dasar dan Pendidikan Menengah

Peraturan Menteri Agama Republik Indonesia Nomor 912 tahun 2013 Tentang Kurikulum Madrasah 2013 Mata pelajaran PAI dan Bahasa Arab

Stake, Robert. E. The Countenance Educational Evaluation, Center for Instructional Research and Curriculum Evaluation University of Illinois Sukiman. 2012. Pengembangan Sistem Evaluasi. Yogyakarta : Insan Madani 